\title{
TEKNOLOGI PERTANIAN BERBASIS EKOLOGI
}

\author{
Kevin ${ }^{1)}$, Budi Adelar Sukada ${ }^{2)}$ \\ 1)Program Studi S1 Arsitektur, Fakultas Teknik, Universitas Tarumanagara, Kevinlukman651@yahoo.com \\ 2) Program Studi S1 Arsitektur, Fakultas Teknik, Universitas Tarumanagara, budisukada@yahoo.com
}

Masuk: 04-07-2021, revisi: 15-08-2021, diterima untuk diterbitkan: 23-10-2021

\begin{abstract}
Abstrak
Pemanasan Global menjadi salah satu penyebab kerusakan ekologi. Pemanasan Global disebabkan oleh aktivitas manusia yang berjalan dengan intensitas tinggi tanpa mempertimbangkan dampak dari aktivitas tersebut. Freight Transport atau yang lebih dikenal sebagai kegiatan logistik merupakan salah satu jenis aktivitas transportasi yang memperburuk keadaan ekologi akibat karbon dioksida dan eksploitasi sumber daya alam. Aktivitas Freight Transport ini sendiri terjadi karena tidak mampunya suatu daerah memenuhi kebutuhannya sendiri sehingga membutuhkan pasokan dari daerah lain. Bangunan dengan Teknologi Pertanian Berbasis Ekologi merupakan solusi dari permasalahan yang ada melalui penyediaan ruang pertanian baru yang memfasilitasi aktivitas pertanian yang sebelumnya tidak dapat dilakukan pada suatu area baik karena ketersediaan lahan maupun kualitas lahan yang tidak memenuhi kriteria ruang pertanian. Bangunan Pertanian ini berlokasi di Desa Pulokerto Kecamatan Gandus Kota Palembang dimana desa ini merupakan area agropolitan yang terancam oleh perkembangan kota dan kerusakan sumber daya tanah. Bangunan ini memiliki program yaitu Pertanian Organik dan Edukasi. Program-program ini difasilitasi oleh sub-program pengolahan limbah dan pengolahan energi secara mandiri melalui Hydroenergy Plant. Sub-program ini bertujuan agar aktivitas pertanian yang ada tidak mengeksploitasi sumber daya tidak terbarukan dan tidak menimbulkan kerusakan lingkungan. Bangunan Pertanian Berbasis Ekologi ini bertujuan memperbaiki dan mengurangi kerusakan ekologi serta menjadi wadah pertanian baru dimana pertanian merupakan salah satu sektor penting untuk kelangsungan kehidupan pada suatu kota.
\end{abstract}

Kata kunci: Agrikultur; Ekologi; Logistik; Pemanasan Global

\begin{abstract}
Global Warming is one of the causes of ecological damage. It is caused by human activities that run at high intensity without considering their impact. Freight Transport, on the other hand, is a type of transportation activity that worsens such a condition due to its production of carbon dioxide and natural resources exploitation it exercises. However, Freight Transport activity occurs because a region requires supplies from other regions due to its disability to meet its own needs. Agricultural Buildings are a solution to such problems by means of providing space that facilitates agricultural activities which could not be carried out because of poor land availability or land quality. This Agricultural Building is located in Pulokerto Village, Gandus District, Palembang City. It is an agropolitan area that is threatened by urban development and creates damage to land resources. As such, it is a compound of buildings that operate the so-called. Organic Agriculture and Education program equipped with waste processing as well as self-sufficient input of energy from hydro-energy plant. This sub-program aims to ensure that existing agricultural activities do not exploit nonrenewable resources and do not cause environmental damage. The compound ultimate is not only to repair and reduce ecological damage but also to become a new agricultural system and become a new agricultural platform where agriculture is one of the important sectors for the survival of life in a city.
\end{abstract}

Keywords: Agriculture; Ecology; Freight Transport; Global Warming. 


\section{PENDAHULUAN}

\section{Latar Belakang}

Logistik atau freight transport yang berhubungan erat dengan kegiatan produksi baik pertanian maupun non pertanian. Adanya permintaan dan penawaran akan kebutuhan pangan menyebabkan tingginya aktivitas logistik / freight transport yang terus menerus merusak lingkungan. Kerusakan kualitas pangan dapat berdampak pada lingkungan. Permasalahan-permasalahan yang ada saat ini diselesaikan dengan bergantung dengan daerah produsen lain dan menyebabkan masalah baru. Hal ini tidak hanya sebatas didistribusikan antar provinsi namun juga antar kota dan kabupaten. Aktivitas distribusi ini tidak hanya terjadi via jalur darat melainkan juga melalui jalur air untuk mengakses daerah tertentu sebagaimana kita ketahui bahwa Indonesia merupakan negara kepulauan yang didominasi oleh perairan.

Logistik merupakan penyumbang emisi nomor 4 terbesar dengan 29.4\% (menurut OurWorldinData.org pada 2019). Keterbatasan lahan menjadi sebab dari permasalahan logistik. Semakin langka atau semakin rendah kemampuan suatu daerah untuk memenuhi kebutuhannya sendiri maka akan semakin tinggi aktivitas logistik. Selain menyumbang emisi, kegiatan logistik juga mengeksploitasi hasil bumi seperti minyak bumi, karet dan logam. (Abdulrahman. 2017)Dalam satu kali perjalanan logistik jarak menengah ( Palembang - Bengkulu sejauh 442 KM ) dibutuhkan 294 liter bahan bakar solar untuk truk kelas menengah (kapasitas 24 ton).

Maka dari itu diperlukan pemikiran untuk menjawab permasalahan berikut, karya arsitektur dituntut untuk menghentikan kerusakan yang ditimbulkan dengan kreatifitas dan terintegrasi. Integrasi yang dimaksud adalah memanfaatkan lahan yang ada dan memfasilitasi pelaku pertanian yang bertujuan untuk meningkatkan efisiensi yang tidak hanya berdampak bagi lingkungan tetapi juga bagi penghidupan manusia yang lebih layak. Dengan fasilitas dan tenaga yang terampil, wadah ini diprediksi akan menjadi produsen pertanian baru yang menghasilkan produk berkualitas dan memberi dampak positif terhadap keadaan ekologi . Bangunan pertanian ini menerapkan sistem pertanian organik dengan pola tanam hidroponik sehingga tidak mengeksploitasi tanah dan dapat meningkatkan kualitas kesuburan tanaman sehingga menghasilkan produk berkualitas.

Pola tanam hidroponik dianggap efektif mengatasi permasalahan keterbatasan lahan dimana pola tanam ini dapat ditanam secara vertikal dengan memanfaatkan fisik bangunan yang dilengkapi fasilitas pertanian seperti sistem pengairan dan pencahayaan dengan memanfaatkan teknologi pertanian berkelanjutan. Melalui sistem dan penerapan teknologi ini diharapkan dapat meningkatkan produktivitas dan kualitas tanaman sehingga dapat memenuhi kebutuhan masyarakat kota Palembang. Dengan pola tanam hidroponik yang lebih efisien dan penggunaan Growing Light, Produktivitas tanaman diprediksi dapat meningkat hingga $\pm 200 \%$ dibanding sistem pertanian konvensional.

\section{Rumusan Permasalahan}

1. Bagaimana merancang ruang agrikultur yang meminimalisir jarak distribusi logistik antara pertanian dan konsumen di perkotaan ?

2. Bagaimana merancang ruang agrikultur yang dapat bertahan seiring perkembangan kota dan pemukiman yang semakin meluas?

3. Bagaimana merancang ruang agrikultur yang berkualitas dan berbasis ekologi ?

\section{Tujuan}

Tujuan proyek ini adalah mengurangi dampak pemanasan global dan kerusakan lingkungan yang ditimbulkan Freight Transport. Proyek ini mengatasi permasalahan yang ada dengan mencari pemecahan masalah melalui penyebab fenomena Freight Transport yaitu keterbatasan fasilitas dan daya dukung lahan. Oleh sebab itu tujuan utama dari proyek ini adalah menghasilkan program dan 
karya arsitektur yang mengatasi keterbatasan dalam bidang pertanian tersebut sehingga dapat memperkecil lingkup pergerakan Freight Transport.

\section{KAJIAN LITERATUR}

\section{Ekologi}

Ekologi berasal dari bahasa Yunani yaitu oikos yang diartikan sebagai rumah atau tempat hidup dan logos yang berarti ilmu. Secara umum ekologi diartikan sebagai ilmu yang mempelajari organisme dalam tempat hidupnya yang sekaligus mempelajari hubungan timbal balik antara organisme dan lingkungannya. ( Effendy harja. 2021). Ekologi hanya mempelajari apa yang ada dan apa yang terjadi di alam. ekologi juga mempelajari mengenai struktur dan fungsi ekosistem atau alam, sehingga dapat menganalisa dan memberi jawaban terhadap berbagai peristiwa alam. (Otto Soemarwoto. 1997)

Struktur ekosistem menurut Odum (1983), terdiri dari beberapa indikator-indikator yang menampilkan keadaan dari sistem ekologi pada waktu dan tempat. Beberapa penyusun struktur tatanan ekosistem antara lain adalah kerapatan, biomas, materi, energi, dan faktor fisik kimia lain yang mengklasifikasikan keadaan sistem tersebut. Dari perpaduan harafiah dan berbagai kajian, maka ekologi dapat diartikan sebagai ilmu yang mempelajari seluruh pola hubungan timbal balik antar mahluk hidup dan juga antara mahluk hidup dengan lingkungannya. Ekologi menjadi jembatan penghubung antara ilmu alam dengan ilmu sosial. ( Odum, E.P. 1983 . Basic Ecology ).

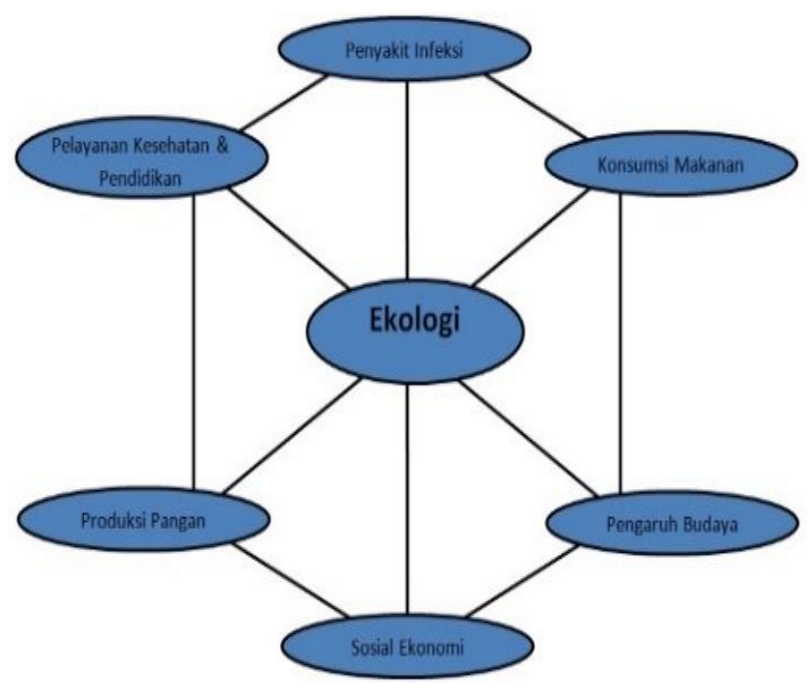

Gambar 1. Indikator Ekologi

Sumber : https://hasanah619.wordpress.com, 2021

\section{Ekologi Arsitektur}

Menurut Ernst Haeckel (1834-1914) dalam Prinsip - Prinsip Ekologi dalam Arsitektur (Mahardika.Wordpress.com) Ekologi Arsitektur adalah suatu konsep untuk melestarikan alam dan lingkungan untuk kehidupan yang berkelanjutan dalam tingkat efisiensi energi dan sumber daya alam dalam kegiatan arsitektural untuk pembangunan yang berkelanjutan dalam mencapai tujuan keberlanjutan lingkungan, ekonomi, sosial dan budaya. Arsitektur yang Ekologis akan tercipta apabila dalam proses berarsitektur menggunakan pendekatan desain yang ekologis yakni mejadikan alam sebagai dasar desain. Proses pendekatan arsitektur yang menggabungkan alam dengan teknologi, menggunakan alam sebagai basis desain dan strategi konservasi sember daya alam sebagai upaya untuk perbaikan lingkungan. Menurut Sukawi (2008) dalam Ekologi Arsitektur: menuju Perancangan Arsitektur hemat energi dan berkelanjutan konsep penekan desain Ekologi Arsitektur didasari dengan maraknya permasalahan global warming, dimana diharapkan konsep yang didasarkan dengan keseimbangan alam dapat menjadi solusi permasalahan isu tersebut. 
Dalam konteks 'ekologi' dan 'arsitektur', kedua istilah ini biasanya saling berkaitan dan dipahami sebagai berkelanjutan, sementara ekologi hanya digunakan secara kualitatif dalam konteks ini. (Resosudarmo. 1992). Pembangunan menyangkut sumber daya terbarukan dan tak terbarukan yang keduanya terbatas dalam eksploitasi. Melampaui ekologi disini mendasari sebuah desain arsitektur agar dapat memecahkan masalah ekologi yang ada dan berhubungan dengan nilai-nilai arsitektur melalui sumber daya atau suatu teknik baru yang dapat digunakan dan juga diterapkan dalam karya tersebut sehingga dapat menghasilkan karya arsitektur yang melampaui ekologi.

\section{Arsitektur Pertanian}

Inovasi arsitektur dibidang pertanian sangat dibutuhkan sebagai solusi untuk mengatasi isu Kepadatan penduduk yang diprediksi dimasa depan akan semakin meningkat. Kepadatan penduduk memiliki hubungan ketergantungan yang sangat erat dengan kebutuhan akan pangan. Ketika kebutuhan pangan tidak dapat mengimbangi kepadatan penduduk tersebut akan berdampak terjadinya krisis ketahanan bahan pangan. Banyak wilayah yang semakin tahun mengalami pembangunan sangat pesat dan menjadi sebuah perkotaan padat. Bidang pertanian merupakan bidang yang terkena dampaknya. Inovasi-inovasi arsitektur pada bidang pertanian dapat berupa sistem , program maupun bentuk fisik bangunan pertanian yang dapat memfasilitasi pelaku pertanian dan memfasilitasi produksi bahan pertanian yang sesuai dengan aturan pembangunan yang berkelanjutan.

\section{Pertanian Organik}

Menurut IASA (dalam Reijntjes et.al., 1997 : 231) Pertanian organik yaitu sistem pertanian yang mendorong kualitas tanah dan tanaman melalui praktek seperti proses daur ulang unsur hara dan bahan-bahan organik, rotasi tanaman, penggarapan yang tepat dan menghindari pupuk sintesis atau kimia serta pestisida. Ini didasarkan pada penggunaan yang minimal dari input di luar pertanian dan pada praktik pengelolaan yang memulihkan, memelihara, dan meningkatkan harmoni ekologis. Menurut Vereesh, (1996 : 58 ) Prinsip dasar pertanian organik berada pada sistem agro, petani harus mengelola pertanian dengan keragaman yang koheren dengan memanfaatkan semua sumber daya di pertanian dan yang berdekatan.

\section{Pertanian Hidroponik}

Hidroponik atau Hydrophonics berasal dari bahasa latin yaitu hydro yang berarti air dan kata Phonos yang berarti daya .(wikipedia.2021) Sistem pertanian yang lebih mengutamakan penggunaan air sebagai sumber nutrisi utama tanaman ini biasanya dilakukan di dalam greenhouse. Selain itu, dengan bercocok tanam hidroponik dapat mengatasi permasalahan keterbatasan lahan, waktu, dan cara pemeliharaan. Hidroponik merupakan salah satu sistem pola tanam pertanian masa depan yang dapat diterapkan di berbagai tempat. Tanaman dapat tumbuh lebih pesat dan dengan keadaan yang tidak kotor dan rusak. Tidak ada resiko yang dapat mengancam keberlangsungan pertumbuhan tanaman seperti kebanjiran, erosi, kekeringan atau ketergantungan pada kondisi alam.

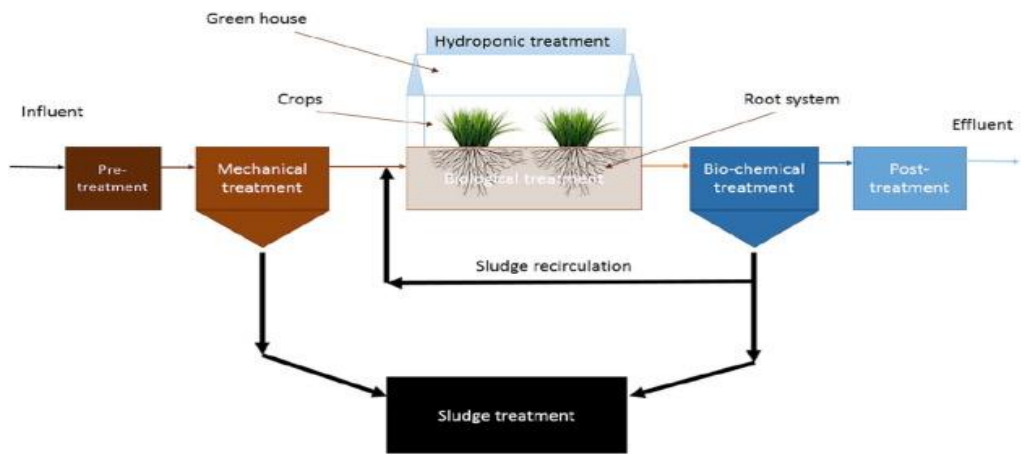

Gambar 2. Pola Tanam Pertanian Hidroponik Sumber : Budidaya.id, 2021 


\section{Jenis Tanaman}

Tabel 01. Jenis Tanaman

\begin{tabular}{lll}
\hline No & \multicolumn{1}{c}{ Jenis Tanaman } & \multicolumn{1}{c}{ Masa Tanam } \\
\hline 1. & Pakcoy & 3 Minggu \\
\hline 2. & Selada & 3 - 4 Minggu \\
\hline 3. & Kangkung & $4-5$ Minggu \\
\hline 4. & Bayam & $4-5$ Minggu \\
\hline 5. & Tomat & $6-8$ Minggu \\
\hline 6. & Cabai & 8 - 10 Minggu \\
\hline 7. & Buncis & $5-6$ Minggu \\
\hline 8. & Timun & 8 Minggu \\
\hline
\end{tabular}

Sumber : dokumen pribadi, 2021

\section{METODE}

\section{Survey Lapangan}

Survey dilakukan di sekitar lokasi tapak dengan mengkaji fenomena-fenomena yang terdapat dilapangan. Survey dimulai dengan pendataan secara visual elemen-elemen pembentuk yang ada secara fisik dan aktivitas warga di sekitar tapak serta para pendatang. Tapak berada di tepi Sungai Musi dan berada tepat di tengah pemukiman masyarakat Pulokerto. Sekitar tapak didominasi oleh pemukiman, lahan gambut dan beberapa lahan pertanian warga. Tepat berada pada sisi kiri tapak adalah rumah panggung asli Desa Pulokerto dan berbatasan langsung dengan Sungai Mancak yang digunakan sebagai sumber.

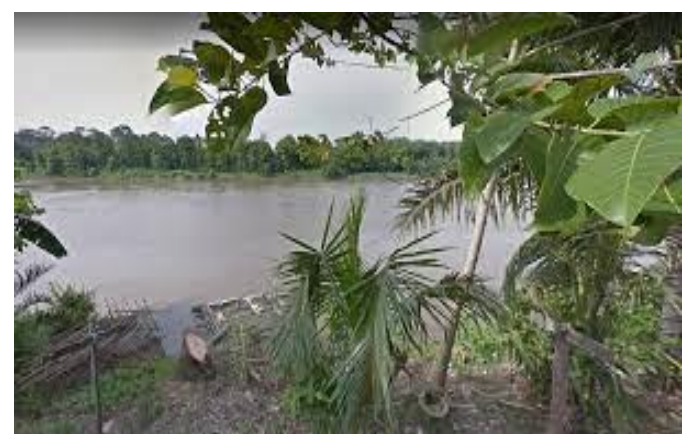

Gambar 3. Kondisi Eksisting Tepi Sungai Musi Sumber : dokumen pribadi, 2021
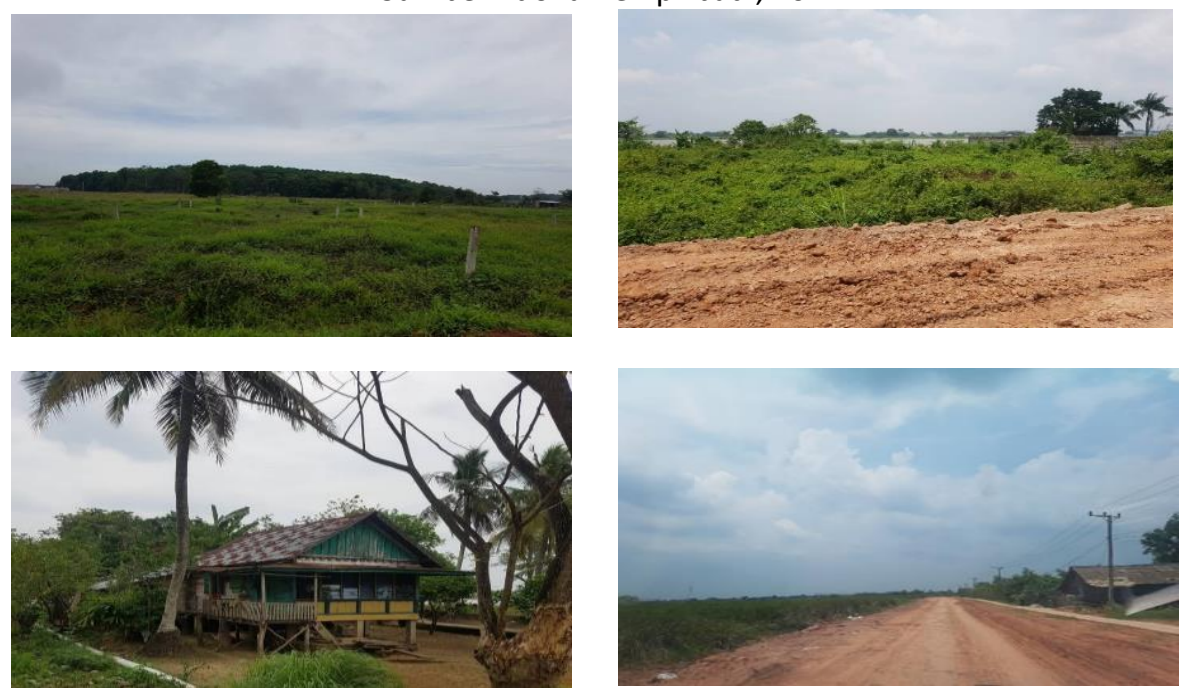

Gambar 4. Kondisi Eksisting Tapak

Sumber : Dokumen Pribadi, 2021 
Pemukiman masyarakat Pulokerto didominasi rumah panggung yang bertujuan menghindari banjir apabila terjadi pasang air laut yang dapat meningkatkan permukaan air sungai Musi. Masyarakat Desa Pulokerto rata-rata bermata pencaharian sebagai buruh pabrik namun profesi ini baru mereka tekuni selama 5 tahun terakhir karena sebelumnya mereka adalah petani dan nelayan. Peralihan profesi ini terjadi akibat berkurangnya lahan pertanian yang dapat mereka garap. Terdapat beberapa lahan yang beralih fungsi menjadi pemukiman baru yang dikembangkan oleh pemerintah kota. Masyarakat Desa Pulokerto memiliki pengalaman pada bidang agrikultur yang mempuni bahkan pertanian merupakan bagian dari tradisi mereka. Tapak berada di sisi jalan desa penghubung kecamatan sedang dalam tahap pembangunan (lihat gambar 06) , dimana langsung terhubung dengan jalan Mayjen Singedekane dan jalan tol Palindra ( exit Gandus ). Melalui jalan ini, proses distribusi dapat berjalan dengan lancar dan mengurangi aktivitas logistik.

\section{Strategi Design}

Strategi yang diterapkan pada rancangan mengacu pada prinsip pertanian berbasis ekologi sehingga dapat mencapai tujuan utama yaitu kondisi ekologi yang semakin membaik dan mengurangi aktivitas logistik yang berdampak pada ekologi. Prinsip yang diterapkan adalah :

\section{- Supply Chain}

Mengutamakan distribusi dari produsen menuju konsumen secara langsung sehingga tidak memerlukan ditampung terlebih dahulu yang dapat menurunkan kualitas dan meningkatkan harga pangan.

\section{- Food Sovereignty}

Berpengaruh terhadap kehidupan lingkungan dan pelaku pertanian yang lebih layak dengan memfasilitasi para pelaku pertanian sehingga menghasilkan program pertanian yang efisien.

\section{- Produksi dan Konsumsi Cerdas}

Memastikan keamanan dan kesehatan pangan tanpa merusak lingkungan dengan menggunakan sistem bangunan dan sistem pertanian yang tidak merusak lingkungan.

\section{- Keanekaragaman Hayati}

Mengembangkan keragaman alam dan proses pembenihan hingga menjadi hasil produksi serta memfasilitasi proses pembenihan , pendederan hingga siap dipanen dan bersifat polikultur.

\section{- Kesuburan Tanah dan Kelestarian Alam}

Melindungi dan meningkatkan kesuburan tanah dengan tidak mengeksploitasi tanah , air tanah dan meningkatkan produktifitas suatu lahan serta tidak menimbulkan pencemaran.

- Pengelolaan Hama

Mengendalikan hama dengan taktik dan bahan alami dengan melindungi sistem yang dapat mengendalikan hama

- Efektifitas dan Durabilitas

Memanfaatkan sumber daya yang ada dan bertahan dari ancaman peralihan lahan melalui energi terbarukan yang terdapat pada daerah sekitar tapak dan memaksimalkan lahan non-produktif.

\section{Sistem dan Produktivitas}

Sistem Pertanian Organik

Bangunan pertanian ini menerapkan sistem pertanian organik, sistem ini diterapkan dengan tujuan kondisi lingkungan yang berkelanjutan sehingga kondisi ekologi dapat terus membaik. Sistem pertanian organik ini dianggap dapat berjalan dengan durasi waktu yang panjang seiring dengan 
banyaknya kampanye pertanian berkelanjutan yang bertujuan untuk meninggalkan pertanian konvensional yang dianggap merusak lingkungan melalui penggunaan bahan kimia dan mengeksploitasi tanah. Melalui sistem pertanian organik ini produk yang dihasilkan akan lebih berkualitas dan sehat dengan memanfaatkan zat-zat alami seperti kompos sebagai perangsang pertumbuhan tanaman.(Rachman Sutanto. 2002) Zat perangsang alami ini didapatkan dari sampah dedaunan, gabah padi yang didapat dari persawahan sekitar lokasi bangunan dan kotoran hewan yang didapat dari peternakan warga yang berada di kecamatan Gandus.

Pola Tanam Hidroponik

Pola tanam hidroponik dipilih karena lebih memudahkan pengawasan dan pemberian nutrisi pada tanaman. Pola tanam hidroponik juga lebih efisien terhadap pemanfaatan ruang sehingga dapat diterapkan pada bangunan vertikal dengan luas lahan yang terbatas. Melalui bangunan pertanian vertikal ini produk yang dihasilkan dapat lebih banyak dibanding lahan pertanian konvensional ( pada luas lahan yang sama ). Pola tanam hidroponik juga dapat meningkatkan kuantitas produk hingga $200 \%$ dibanding pola tanam konvensional.

Produktivitas

Pada bangunan pertanian ini kualitas lebih diutamakan dibanding kuantitas namun seiring dengan penerapan pola tanam hidroponik dan penggunaan teknologi LED Growing Light produktivitas tanaman akan meningkat hingga $\pm 200 \%$ karena tanaman tidak bergantung pada kandungan nutrisi yang ada di tanah dan sinar matahari alami yang tidak menentu. Dengan penerapan sistem pertanian organik dan pola tanam hidroponik serta diiringi dengan teknologi yang berkelanjutan diharapkan bangunan pertanian ini memiliki nilai produktivitas yang tinggi sehingga dapat bermanfaat bagi masyarakat kota Palembang dan mengurangi dampak kerusakan ekologi.

\section{DISKUSI DAN HASIL}

\section{Analisa Tapak \& Gubahan Massa}

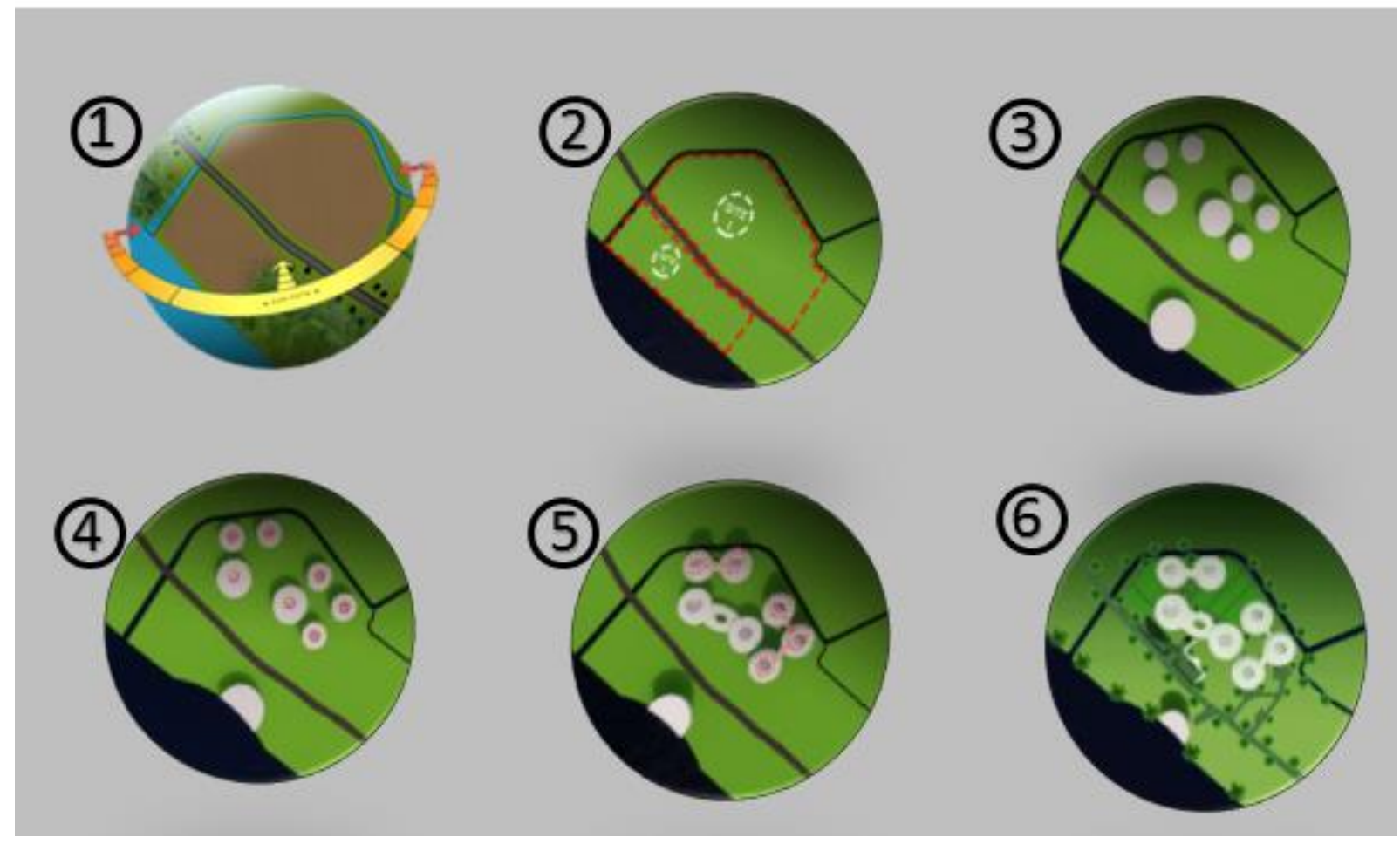

Gambar 5. Design Scheme

Sumber : Dokumen Pribadi, 2021 
1. Orientasi massa menghadap arah orientasi matahari sehingga dapat memanfaatkan pencahayaan alami

2. Membagi tapak sesuai zoning dan menaati peraturan Rencana Tata Guna Lahan dan Lingkungan

3. Perletakan massa bangunan sesuai zoning dan aktivitas yang disesuaikan dengan potensi yang terdapat pada tapak

4. Massa berbentuk lingkaran bertujuan memaksimalkan masuknya cahaya matahari kedalam bangunan yang didukung dengan penggunaan void. Void ini juga berfungsi untuk menciptakan sirkulasi udara yang nyaman pada bagian dalam bangunan.

5. Koneksi antar massa berupa connecting bridge berfungsi untuk memfasilitasi aktivitas pertanian. ( sirkulasi )

6. Pemanfaatan lahan sisa (KDH) sebagai lahan pertanian terbuka, Lahan sisa ini juga dapat digunakan sebagai strategi spekulatif apabila dibutuhkan perluasan massa bangunan.

Dari hasil analisa dan transformasi gubahan didapatkan gubahan akhir yang telah melewati serangkaian proses berdasarkan data dan fenomena yang terdapat pada lokasi tapak. Gubahan kemudian dilanjutkan kedalam proses desain selanjutnya. Yaitu memasukan ruang-ruang dan penerapan sistem sesuai dengan strategi design yang telah didtetapkan. Selanjutnya 7 strategi design tersebut dimasukan kedalam susunan konsep dan analisa kebutuhan ruang. Penyusunan ruang dilakukan secara vertikal dan horizontal tergantung pada besaran dan hubungan antar ruang satu sama lain. Gubahan akhir yang didapat dijadikan acuan namun tidak menutup kemungkinan adanya perubahan-perubahan minor yang dilakukakan selama proses desain.

\section{Proses \& Aktivitas}

Proses penanaman hingga proses panen tetap sama dengan pertanian konvensional, hal ini bertujuan untuk tidak menghilangkan nilai-nilai pertanian tradisional yang telah diterapkan warga desa Pulokerto sebelumnya. Peralatan dan fasilitas yang diterapkan pada bangunan bertujuan memfasilitasi para pelaku pertanian. Sistem pencahayaan dan utilitas dirancang sesuai dengan kebutuhan untuk mendukung proses tumbuh tanaman agar lebih efisien dan berkualitas. Aktivitas pertanian berlangsung selama 8 jam setiap hari dengan pembagian tugas sesuai dengan pembagian ruang bilik penanaman. Proses pembibitan dilakukan pada ruangan khusus untuk mengantisipasi pencahayaan yang berlebihan dan memudahkan proses pengawasan. Pada setiap ruang penumbuhan diberi sekat dan jaring paranet untuk mencegah serangan hama yang dapat menghambat dan merusak pertumbuhan tanaman. Bangunan terbagi atas beberapa bilik yang bertujuan untuk membagi ruang tanam sesuai dengan jenis tanaman dan mencegah kerusakan tanaman secara global. Pembagian ini juga bertujuan memudahkan pengawasan dan pemberian nutrisi oleh perlaku pertanian.

\section{Dimensi \& Organisasi Ruang}

Penetapan dimensi pada ruang dalam bangunan disesuaikan dengan ergonomi tubuh manusia mengacu pada nilai yang terdapat pada buku Human Dimension dan Neufert Data Arsitek yang disesuaikan kembali dengan ergonomi tubuh masyarakat lokal. Penetapan dimensi peralatan seperti rak hidroponik, gudang peralatan, peralatan servis juga disesuaikan dengan ergonomi tubuh pelaku pertanian. Peralatan dan furniture disesuaikan dengan kebiasaan pelaku pertanian seperti penggunaan kloset jongkok. 


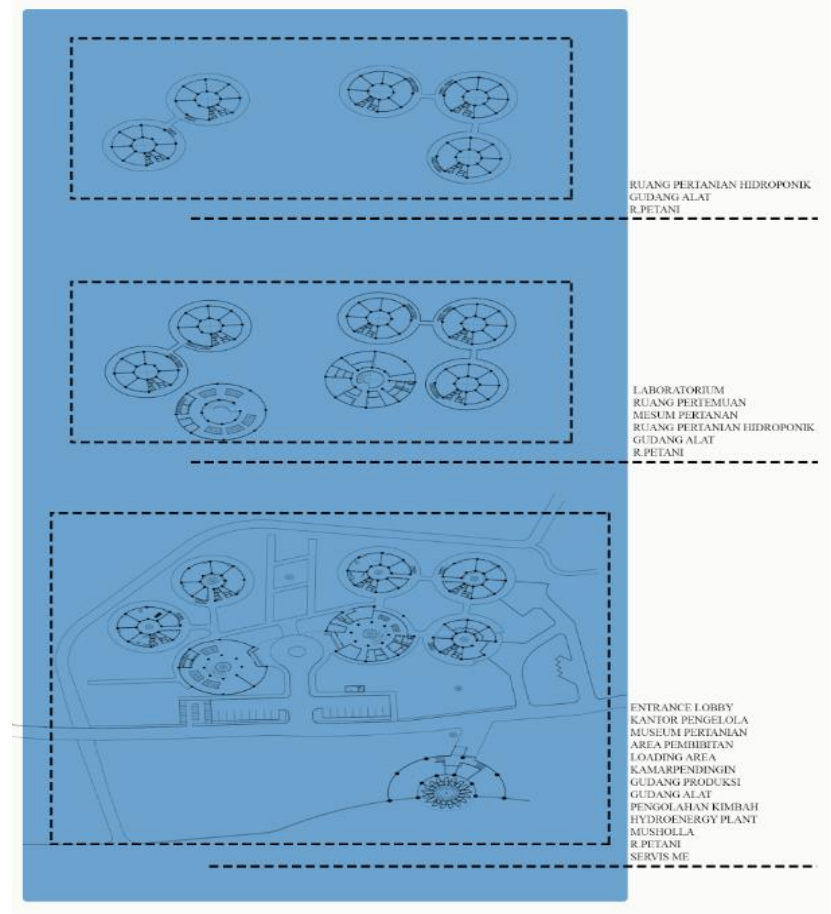

Gambar 6. Pengorganisasian ruang

Sumber : Dokumen Pribadi, 2021

Program bangunan dikelompokkan menjadi Pertanian, Edukasi dan Pengolahan. Bangunan menerapkan sistem yang dapat memfasilitasi program-program tersebut sehingga para pelaku aktivitas dapat menjalankan aktivitasnya secara efektif. Pertanian menerapkan sistem pertanian organik dengan pola tanam hidroponik yang mengutamakan kualitas dibanding kuantitas. Melalui sistem ini tanaman dapat tumbuh dengan sehat dan memberi dampak positif terhadap lingkungannya. Program edukasi berperan sebagai penambah ilmu pengetahuan masyarakat mengenai bidang pertanian serta berperan sebagai media penarik minat kaum milenial terhadap bidang pertanian agar para pelaku pertanian dapat terus ber-regenerasi

Melalui program pengolahan, dampak yang ditimbulkan oleh aktivitas pertanian dapat teratasi yaitu pengolahan limbah pertanian yang dilakukan untuk meningkatkan nilai dari limbah tersebut yaitu menjadi pupuk organik. Pupuk ini dapat digunakan untuk menstimulun pertumbuhan tanaman pada pertanian hidroponik maupun pertanian konvensional melalui proses fermentasi dengan penambahan bakteri dari kompos. Program-program diatas didukung oleh program pengolahan energi listrik dengan memanfaatkan arus sungai yang terdapat pada tapak. Program ini bertujuan untuk meminimalisir penggunaan sumber daya tidak terbarukan serta mengurangi dampak dampak negatif terhadap lingkungan.

Melalui proses pemrograman tersebut didapatkan pengorganisasian ruang berdasarkan proses desain dan dilanjutkan dengan pengolahan denah dengan melakukan serangkaian studi ergonometri dan studi kasus dari proyek-proyek sejenis. Melihat dari sasaran pengguna bangunan (user) yang adalah petani tradisional, pengolahan denah dibuat lebih sederhana, Konsep desain ruang terinspirasi dari teori Proxemics oleh Edward T. Hall. Dalam teorinya Hall menyebutkan bahwa manusia memiliki personal space yang diilustrasikan dengan lingkaran disekitar tubuh manusia. Lingkaran tersebut direpetisi dan diilustrasikan menjadi lingkaran-lingkaran yang saling bertumpuk menghasilkan bentuk baru. (Edward T.Hall . 1966) Bentuk tersebut dimasukan kedalam bangunan dan digunakan untuk mendesain ruang-ruang termasuk lanskap.

Pada sekitar tapak terdapat bangunan asli desa pulokerto yaitu rumah panggung dimana rumah ini memiliki elemen tangga sebagai alat sirkulasi yang menghubungkan teras dan halaman rumah. Elemen 
ini diterapkan pada bangunan melalui penggunaan tangga yang diletakan pada bagian luar bangunan sebagai jalur pencapaian menuju lantai 2 berupa balkon yang berfungsi sebagai selasar penghubung antar ruang pertanian.

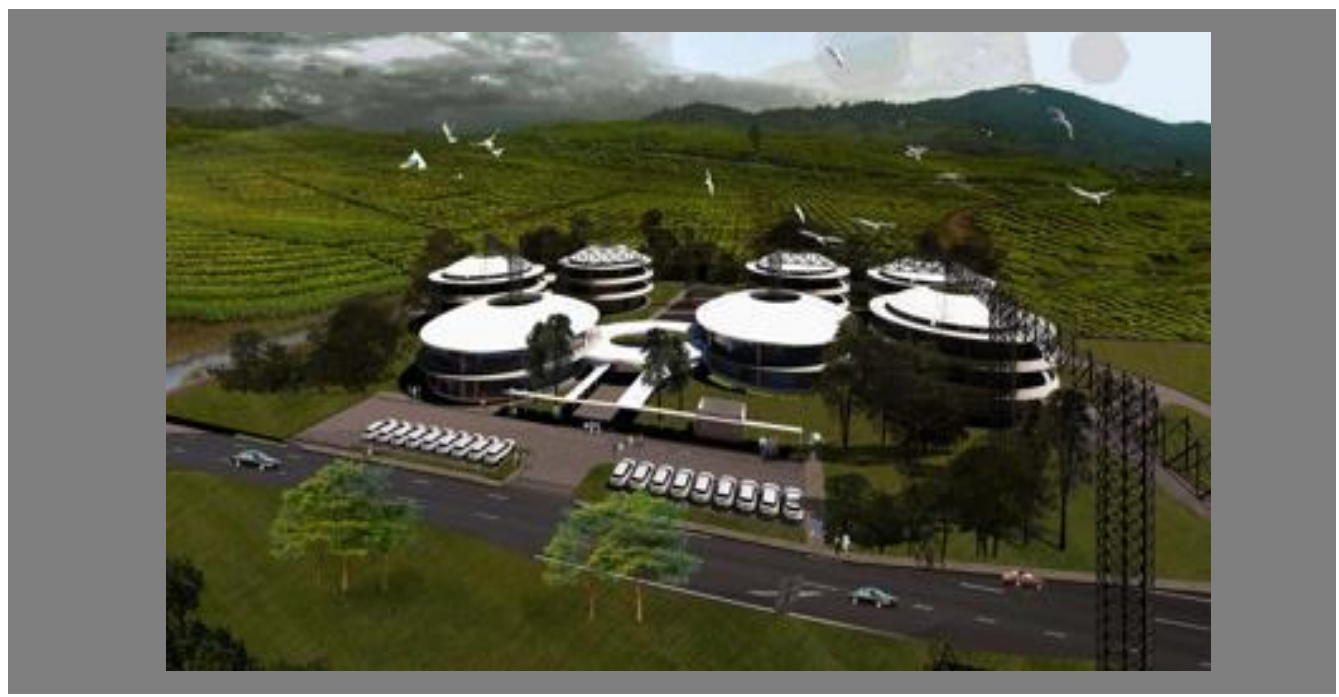

Gambar 7. Perspektif Eksterior Sumber : Dokumen Pribadi, 2021

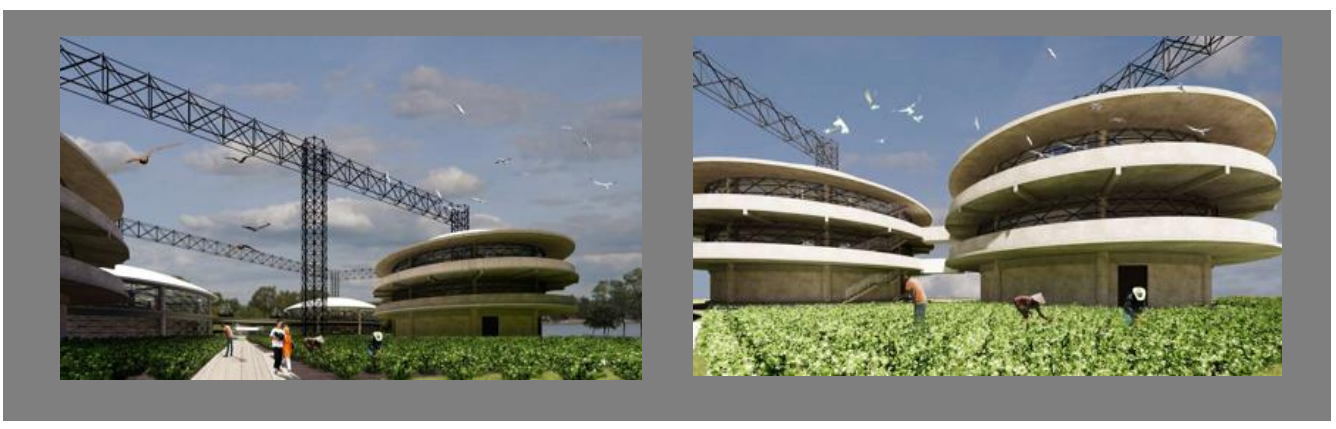

Gambar 8. Perspektif Pertanian

Sumber : Dokumen Pribadi, 2021

Interior bangunan menerapkan elemen pertanian sederhana sebagaimana yang sering digunakan pada pertanian tradisional. Elemen-elemen ini juga merupakan adaptasi dari pelaku aktivitas pertanian dimana masih menggunakan elemen arsitektur tradisional seperti penggunaan toilet jongkok dan bak air pada toilet. 


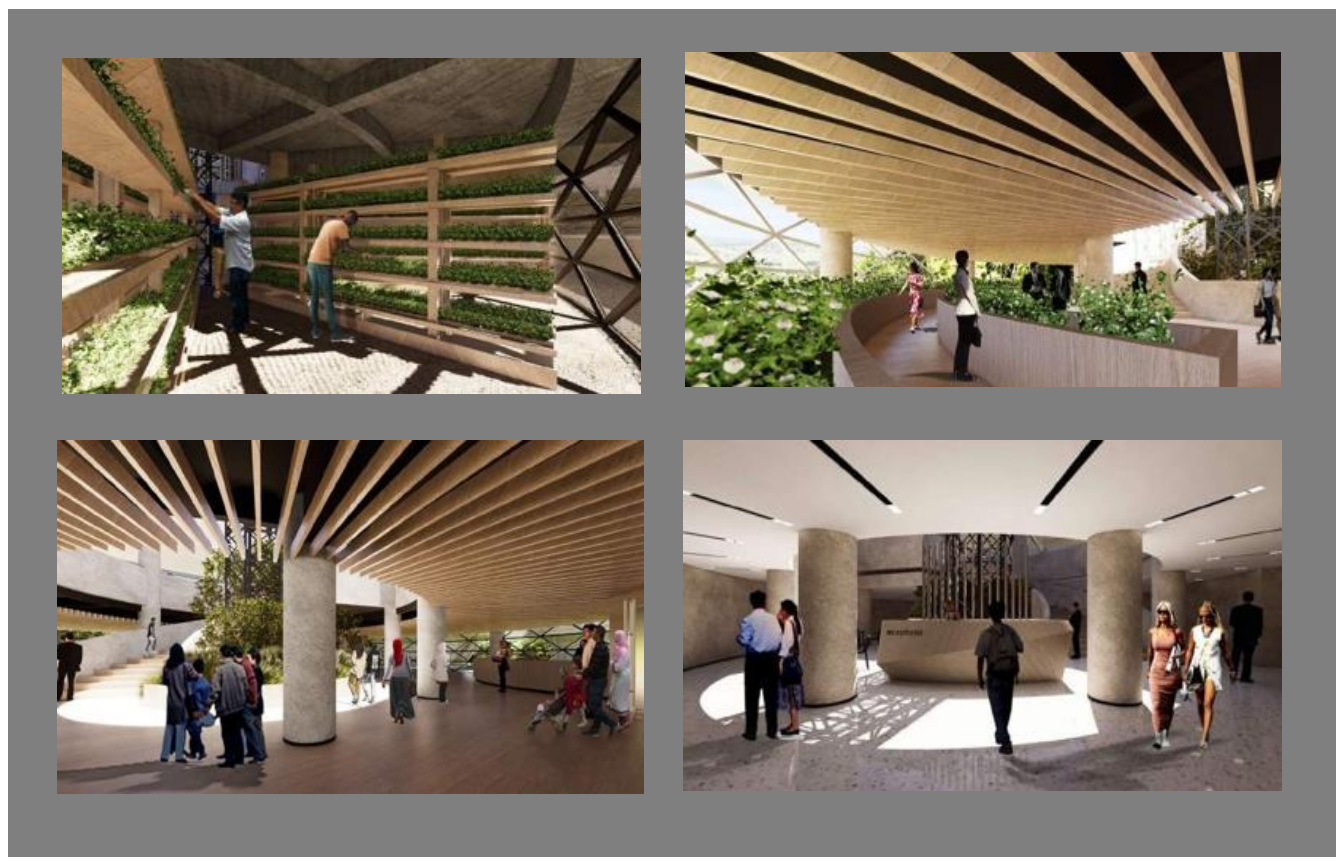

Gambar 9. Perspektif Interior

Sumber : Dokumen Pribadi, 2021

\section{KESIMPULAN DAN SARAN KESIMPULAN}

Bangunan Pertanian dengan Teknologi Berbasis Ekologi merupakan bangunan pertanian yang mewadahi para pelaku pertanian sehingga menciptakan bidang pertanian yang lebih efisien dan nyaman. Bangunan ini bertujuan mengurangi dampak pemanasan global dan kerusakan lingkungan yang ditimbulkan Freight Transport dimana fenomena ini sering terjadi di Indonesia terutama kota Palembang. Melalui bangunan ini, aktivitas freight transport dapat dikurangi akibat jarak distribusi yang singkat karena keberadaan bangunan ini berada dekat dengan konsumen. Melalui fasilitas dan sistem pertanian organik dengan pola tanam hidroponik yang diterapkan pada bangunan ini, diharapkan dapat menghasilkan produk pangan yang berkualitas dan diiringi dengan faktor pendukung seperti petani dan lingkungan yang semakin berkembang. Proses perancangan dan konsep disusun sesuai dengan strategi desain berdasarkan indikator teknologi pertanian berbasis ekologi. Proses gubahan dan pengolahan tapak terbagi atas 3 bagian yaitu massa utama ( kantor \& edukasi ), massa pertanian, massa fasilitas servis ( MEP, Loading dock, Hydroenergy). Pengorganisasian ruang disusun berdasarkan alur aktivitas dan intensitas penggunaan ruang. Dimensi ruang pertanian disusun berdasarkan ergonomi tubuh manusia yang disesuaikan kembali terhadap postur tubuh masyarakat lokal.

Bangunan ini diharapkan dapat mewadahi aktivitas di bidang pertanian melalui program yang terdapat pada proyek ini yaitu pertanian organik, pengolahan limbah, hydroenergy plant, dan edukasi yang menerapkan sistem-sistem yang tidak menghasilkan dampak negatif terhadap lingkungan terutama air dan tanah. Bangunan ini terletak di Desa Pulokerto, Kecamatan Gandus Kota Palembang dimana kawasan ini memiliki potensi pertanian karena merupakan kawasan Agropolitan. Sumber daya manusia di kawasan ini memiliki pengalaman dibidang pertanian bahkan pertanian merupakan bagian dari budaya dan tradisi masyarakat desa Pulokerto sehingga bangunan ini tidak hanya memberi dampak positif bagi konsumen di perkotaan namun juga berdampak terhadap masyarakat lokal desa Pulokerto melalui wadah pertanian baru yang efisien dan nyaman. Dengan lokasi yang berada dalam radius $5 \mathrm{~km}$ dari Kota Palembang, bangunan ini diharapkan dapat menekan laju freight transport dan membantu memenuhi ketersediaan pangan di Kota Palembang. 


\section{SARAN}

Melalui Bangunan Pertanian dengan Teknologi Berbasis Ekologi, bidang pertanian telah berusaha mengurangi dampak kerusakan ekologi oleh sebab itu sub-sektor usaha lain diharapkan dapat mendukung dan memperkuat tujuan bangunan pertanian ini. Menjadikan konsep ekologi bangunan pertanian ini sebagai acuan dalam merancang wadah pertanian baru. Pengembangan sektor pangan lainnya lebih dapat mengutamakan kualitas daripada kuantitas sehingga menciptakan produk dan lingkungan yang lebih baik. Teknologi pertanian berbasis ekologi ini diharapkan dapat diterapkan pada lahan-lahan pertanian yang lain dan dapat terus berjalan seiring dengan perkembangan sektor pertanian yang ada.

\section{REFERENSI}

Abdulrahman.(2017) Ini Peran Industri Logistik Terhadap Kualitas Udara. Diunduh pada 18 Febuari 2021 Dari https://ekonomi.bisnis.com/read/20171203/98/714783/ini-peranindustri-logistik-terhadap-kualitas-udara

Edward T.Hall (1966) Proxemic Theory. Dalam https://laofutze.wordpress.com/ Diunduh pada 04 Maret 2021 Dari https://laofutze.wordpress.com/2014/01/03/e-t-hall-proxemicsunderstanding-personal-space/

Effendi, Harja (2021).Ekologi \& Hewan. Diunduh pada 18 Febuari 2021 Dari https://slideplayer.info/slide/18049458/

Haeckel, Ernst (1834-1914) Prinsip-Prinsip Ekologi dalam Arsitektur. Diunduh pada 18 Febuari 2021 dari Mahardika.Wordpress.com

Neufert, E. Data Arsitek Edisi 33 jilid 1 \& 2, Erlangga, Jakarta

Oddum, Eugene P. 1983. Basic Ecology. Philadelphia ; New york : Holt-Saunders International Editions. Terjemahan Gadjah Mada University Press, 1993

Otto Soemarwoto. (1997). Ekologi, Lingkungan Hidup dan Pembangunan. Jakarta: Djambatan

Rachman Sutanto. (2002). Inventarisasi Teknologi Alternatif Dalam Mendukung Pertanian Berkelanjutan. Buku B. Yogyakarta : Fakultas Pertanian UGM

Resosudarmo, R.S.; K. Kartawinata; A. Soegiarto. (1992). Pengantar ekologi. Penerbit Remaja Rosdakarya. Bandung.

Ritchie Hanna. 2020. Cars, planes, trains: where do CO2 emissions from transport come from?. https://ourworldindata.org/co2-emissions-from-transport

Reijntjes, Coen, at. al. (1992). Farming for The Future, An Introduction to Low-External - Input andSustainble Agriculture. (Eleske Van de Fliert dan Bernadus Hidayat. Terjemahan). London dan Basingstoke : The Macmillan Press Ltd.

Sukawi, Sukawi (2008) EKOLOGI ARSITEKTUR MENUJU PERANCANGAN ARSITEKTUR HEMAT ENERGI DAN BERKELANJUTAN. In: Simposium RAPI VII, Jurusan Arsitektur Fakultas Teknik Undip.

Veeresh, G. K., et al.. (1996). Organic Farming and Suistainble Agriculture. Banglore: Association For Promotion of Organic Farming

Wikipedia. (2021). Pertanian Hidroponik. Diunduh pada 23 Febuari 2021 Dari https://id.wikipedia.org/wiki/Hidroponik 